\title{
PEMBINAAN KEMAMPUAN MENULIS PUISI DI PADEPOKAN IQRO DESA KOLAM KECAMATAN PERCUT SEI TUAN KABUPATEN DELI SERDANG
}

\author{
Abdurahman Adisaputera ${ }^{*}$, Wisman Hadi $^{2}$, Trisnawati Hutagalung ${ }^{3}$ \\ Jurusan Bahasa dan Sastra Indonesia, Fakultas Bahasa dan Seni, Universitas Negeri Medan, Medan, \\ Indonesia \\ *Penulis Korespondensi: trisnawati.hutagalung@yaho.co.id
}

\begin{abstract}
Abstrak
Menulis adalah kegiatan mengolah isi pikiran yang dituangkan melalui tulisan. Tujuan pelaksanaan kegiatan ini adalah untuk meningkatkan kemampuan anak-anak di Padepokan Iqro Desa Kolam dalam menulis puisi. Meningkatnya kemampuan menulis puisi menjadi langkah awal untuk mempengaruhi minat anak-anak di Padepokan dalam memperkaya pengetahuan berliterasi sastra yang dimiliki. Karena salah satu kegiatan dalam berliterasi adalah menulis. Untuk itu diperlukan tindak lanjut, dalam hal ini pembinaan menulis puisi terhadap anak-anak di Padepokan Iqro Desa Kolam Kecamatan Percut Sei Tuan Kabupaten Deli Serdang. Metode yang dilakukan dalam pembinaan kemampuan menulis puisi ini adalah metode pelaksanaan dengan 3 tahapan yaitu tahap workshop, tahap pembimbingan dan tahap pembuatan laporan hasil kegiatan, juga metode pendekatan yaitu metode pendidikan, metode pelatihan dan praktik, metode bimbingan dan praktik. Hasil kegiatan pembinaan kemampuan menulis puisi tersebut mendapat respon yang positif oleh kelompok sasaran. Anak-anak di Padepokan memiliki antusiasme yang tinggi dalam kegiatan tersebut, terlihat dari keaktifan anak-anak dalam tanya jawab. Anak-anak mulai mampu menulis puisi dengan baik. Kemampuan itu dapat di lihat melalui buku berISBN yang berisikan kumpulan puisi hasil tulisan anak-anak di Padepokan secara individu, yang menjadi luran dari pengabdian tersebut.
\end{abstract}

Kata kunci : Pembinaan, Kemampuan, Menulis Puisi

\begin{abstract}
Writing is an activity to process the contents of the mind as expressed in writing. The purpose of this activity is to improve the ability of children in Padepokan Iqro Desa Kolam in writing the poetry. Increasing the ability to write poetry is the first step to influence children's interest in Padepokan in enriching their literary literary knowledge. Because one of the activities in literacy is writing. For this reason, a follow-up is needed, in this case, coaching in writing the poetry for children in Padepokan Iqro, Kolam Village, Percut Sei Tuan District, Deli Serdang Regency. The method used in coaching the ability to write poetry is the implementation method with 3 stages, namely the workshop stage, the guidance stage and the activity result report-making stage, as well as the approach method, namely the educational method, training and practice methods, guidance and practice methods. The results of the poetry writing skills development activities received a positive response from the target group. Children in Padepokan have high enthusiasm for these activities, it can be seen from the activity of the children in question and answer. Children begin to be able to write a poem is good. This ability can be seen through the ISBN book which contains a collection of poems written by the children in Padepokan individually, which are part of this dedication.
\end{abstract}

Keywords: Coaching, Ability, Writing the Poetry

\section{PENDAHULUAN}

Kemampuan berliterasi harus dikembangkan sejak dini. Silaen dan Hasfera (2018) mengungkapkan bahwa para pendiri bangsa yang mengantarkan Indonesia menjadi negara yang merdeka dan bermartabat adalah orangorang dengan budaya literasi yang sangat baik. Artinya, orang orang terdahulu adalah para pembaca buku dan menuangkan pemikiran-pemikirannya dengan menulis. 
Kenyataan yang ditemukan, banyak masyarakat yang tidak menyadari bahwa kurangnya keinginan membaca dan menulis sejalan dengan kemampuan literasi yang dimiliki. Masyarakat akan terancam kehilangan kemampuan berliterasi mereka jika mereka tidak membiasakan diri untuk menggali informasi dengan membaca dan menuangkannya dalam tulisan.

Wurianto (2017) menungkapkan bahwa literasi telah berkembang pada masyarakat lisan. Sebagaimana perkembangan sastra Indonesia, berkembang dari tradisi lisan ke tradisi tulis. Demikian pula dengan literasi, perihal "hal belajar" bahwa awal literasi di Indonesia adalah Literasi Sastra. Hal ini menunjukkan, bahwa sastra memiliki kedudukan penting dalam pembelajaran. Sebagaimana diketahui bahwa literasi sasta membangun nilai-nilai etika, estetika, dan moral terabsorbsi secara luas.

Salah satu cakupan dalam literasi adalah menulis. Gie (2002) menyebutkan bahwa menulis adalah segenap rangkaian kegiatan seseorang dalam rangka mengungkapkan gagasan dan menyampaikannya melalui bahasa tulis kepada orang lain agar mudah dipahami. Dengan kata lain, menulis dapat dimaknai sebagai kegiatan mengolah isi pikiran yang dituangkan melalui tulisan.

Salah satu cakupan sastra adalah puisi. Puisi disebut juga ucapan atau ekspresi tidak langsung atau ucapan ke inti pati masalah, peristiwa, ataupun narasi (Pradopo, 2005: 314). Adapun unsur-unsur yang membangun sebuah puisi, yaitu :

a. Tema

Tema adalah landasan atau dasar pijakan bagi penyair untuk mengembangkan puisi. Tema juga merupakan gagasan pokok yang diungkapkan dalam sebuah puisi.

b. Perasaan/Rasa

Rasa adalah ungkapan atau ekspresi penyair kepada sesuatu yang dituangkan ke dalam puisinya. Rasa juga merupakan cara bagaimana penyair mengejawantahkan bentuk perasaan dan pengalaman batinnya kepada keahlian untuk memilih kata-kata figuratif yang dianggap dapat mewakili perasan atau ekspresinya terhadap sesuatu.

c. Nada dan Suasana

Nada adalah bentuk sikap atau keinginan penyair terhadap pembaca. Apakah penyair lewat puisinya ingin memberikan nasihat, menyindir, mengkritik, atau mengejek pembaca. Suasana adalah akibat yang ditimbulkan puisi terhadap jiwa pembaca. Nada dan suasana memiliki kaitan yang erat. Nada puisi yang bersifat kesedihan dapat membuat perasaan pembaca merasa iba. Nada yang mengandung kritikan membuat suasana hati pembaca merasa ingin memberontak dan sebagainya.

d. Pesan atau Amanat

Pesan atau amanat adalah hal yang ingin disampaikan oleh penyair kepada pembaca lewat kata-kata dalam puisinya.

Salah satu metode yang dapat digunakan dalam menulis puisi adalah metode drill (latihan). Zuhairini (2008:106) memaparkan bahwa metode drill (latihan) adalah suatu metode dalam pendidikan dan pengajaran dengan jalan melatih siswa terhadap bahan pelajaran yang sudah diberikan. Artinya dengan latihan menulis puisi yang dilakukan secara berulang, dapat membantu meningkatkan kemampuan seseorang dalam menulis puisi.

Padepokan Iqro Desa Kolam memfasilitasi anak-anak dalam belajar. Ada banyak buku yang seharusnya dapat menjadi media anak-anak untuk menumbuhkembangkan kemampuan mereka dalam berliterasi sastra (menulis puisi). Namun, kenyataan yang ditemukan minat baca anak-anak terhadap buku masih kurang. Hal ini disebabkan karena kurangnya metode yang tepat untuk membangun semangat anakanak di Padepokan Iqro Desa Kolam dalam berliterasi sastra yang menyebabkan minat mereka dalam berliterasi sastra masih rendah, terkhusus dalam menulis puisi.

Berdasarkan hasil observasi yang dilakukan pengabdi terhadap Padepokan Iqro Desa Kolam Kecamatan Percut Sei Tuan Kabupaten Deli Serdang, bahwa permasalahan khusus yang dihadapi mitra adalah:

1) kurangnya sosialisasi tentang gerakan literasi sastra di Padepokan Iqro Desa Kolam.

2) kurangnya minat berliterasi sastra anak-anak padepokan Iqro Desa Kolam.

3) kurangnya metode yang tepat untuk membangun semangat anak-anak di Padepokan Iqro Desa Kolam dalam berliterasi sastra terkhusus dalam menulis puisi.

Dalam hal itu, melihat keadaan tersebut, Padepokan Iqro Desa Kolam Kecamatan Percut Sei Tuan Kabupaten Deli Serdang layak diberikan pembinaan kemampuan menulis puisi dengan tujuan membangkitkan antusiasme anak-anak di Padepokan Iqro Desa Kolam dalam berliterasi sastra. Dikarenakan pada era revolusi insdustri 4.0 ini, kemampuan berliterasi sangat penting dimiliki. Tujuan pelaksanaan kegiatan ini adalah untuk membangkitkan minat anakanak di Padepokan Iqro Desa Kolam dalam berliterasi 
sastra dan meningkatkan kemampuan menulis puisi yang mereka miliki. Sehingga dengan metode yang digunakan dalam pembinaan tersebut, dapat menjadi acuan pihak padepokan untuk memberikan pembinaan berkelanjutan setelah terselesaikannya kegiatan pengabdian.

\section{BAHAN DAN METODE}

\section{A. Metode Pelaksanaan}

Tahapan ini dimulai dengan sosialisasi tentang pentingnya gerakan literasi sastra, kemudian dilanjutkan dengan pembimbingan kemampuan berliterasi sastra dalam hal ini menulis puisi terhadap anak-anak di Padepokan Iqro Desa Kolam dengan metode drill (latihan), sampai diperolehnya luaran yang diharapkan yaitu kumpulan puisi hasil karya anak-anak Padepokan Iqro Desa Kolam dalam bentuk buku ber ISBN.

Adapun rincian tahap kegiatan pengabdian ini sebagai kegiatan pembinaan kemampuan berliterasi sastra anak-anak Padepokan Iqro Desa Kolam adalah sebagai berikut:

a. Tahap Workshop

Pada tahap ini dilakukan workshop pada bulan pertama pelaksanaan kegiatan pengabdian. Dimana rincian kegiatannya adalah sosialisasi mengenai pentingnya berliterasi, memperkenalkan gerakan literasi sastra, menyiapkan media-media yang dapat digunakan dalam pembinaan kemampuan menulis puisi.

b. Tahapan Pembimbingan

Tahapan ini dilakukan 6 pertemuan selama empat bulan sampai tercapainya luaran kegiatan yang diharapkan yaitu berupa buku kumpulan puisi hasil karya anak-anak Padepokan Iqro Desa Kolam. Dalam proses pembimbingan ini, anak-anak akan diberi pemahaman mengenai bagaimana berliterasi sastra dalam hal ini menulis puisi, lalu dilakukan pembinaan menulis puisi dengan metode drill (latihan) didampingi oleh tim instruktur kegiatan berliterasi sastra sampai anak-anak mahir menulis puisi dan masing-masing anak menciptakan tulisan puisi yang nantinya akan dibukukan.

c. Tahapan Pembuatan Laporan Hasil Kegiatan Tahap pembuatan laporan adalah tahapan akhir dari rangkaian kegiatan pengabdian masyarakat yang akan dilakukan. Tim pengabdian masyarakat akan menyusun laporan hasil kegiatan yang sudah dilakukan nantinya dan membuat arsip luaran kegiatan laporan serta lampiran-lampiran lain seperti foto-foto kegiatan, sertifikat kegiatan baik untuk peserta maupun instruktur, dan menyusun laporan pertanggungjawaban keuangan yang digunakan selama kegiatan berlangsung.

\section{B. Metode Pendekatan}

Metode pendekatan yang ditawarkan untuk menyelesaikan permasalahan dalam kegiatan pengabdian ini adalah :

a. metode pendidikan dilakukan dengan cara menjelaskan pentingnya memiliki kemampuan berliterasi sastra.

b. metode latihan dan praktik yaitu melatih dan mempraktikkan langsung bagaimana berliterasi sastra yang baik dalam hal ini menulis puisi.

c. bimbingan dan pendampingan dalam penerapan berliterasi sastra untuk mendapatkan hasil tulisan puisi yang baik sesuai dengan yang diharapkan oleh mitra.

\section{HASIL DAN PEMBAHASAN}

\section{A. Pelaksanaan Kegiatan}

Kegiatan pengabdian ini bertujuan memberikan pelatihan pada anak-anak Padepokan Iqro Desa Kolam Kec. Percut Sei Tuan Kabupaten Deli Serdang untuk meningkatkan kemampuan berliterasi sastra mereka, dalam hal ini kemampuan menulis puisi. Dimulai dengan pemaparan materi konsep dasar literasi terkhusus konsep dasar puisi, termasuk di dalamnya teknik menulis puisi dengan metode drill (latihan), kemudian dilanjutkan dengan Pelatihan teknik menulis puisi dengan cara memperkaya kosa kata anak-anak Padepokan Iqro Desa Kolam Kec. Percut Sei Tuan Kabupaten Deli Serdang melalui permainan-permainan, dan pembimbingan menulis puisi terhadap anak-anak Padepokan Iqro Desa Kolam Kec. Percut Sei Tuan Kabupaten Deli Serdang sampai mampu menulis puisi secara mandiri sesuai dengan memasukkan unsur-unsur puisi sehingga diperolehnya luaran yang diharapkan yaitu laporan berupa buku kumpulan puisi ber-ISBN.

Pelaksanaan kegiatan pembinaan ini dilakukan mulai bulan Juli s.d Oktober 2020 dengan empat tahapan yaitu sosialisasi konsep dasar literasi dalam hal ini menulis puisi, pelatihan memperkaya kosa kata dengan permainan-permainan, tahapan pembimbingan menulis puisi, dan diakhiri dengan tahapan laporan buku berISBN yang berisikan puisi yang ditulis oleh anak-anak Padepokan Iqro Desa Kolam Kec. Percut Sei Tuan Kabupaten Deli Serdang setelah dilakukannya pembinaan, rinciannya sebagai berikut.

a. Sosialisasi Pembinaan Berliterasi

Sosialisasi pembinaan kemampuan berliterasi sastra anak-anak Padepokan Iqro Desa Kolam Kec. Percut Sei Tuan Kabupaten Deli Serdang 
dilakukan pada bulan Juli 2020. Dalam solisasi ini dilakukan pemaparan tujuan pembinaan kemampuan berliterasi sastra dan juga pemaparan materi yang berhubungan dengan literasi sastra. Materi yang dipaparkan adalah: (1) hakikat literasi sastra, (2) hakikat puisi, (3) hakikat menulis dan (4) teknik menulis puisi dengan metode drill (latihan). Dari kegiatan sosialisasi ini terlihat anak-anak Padepokan Iqro Desa Kolam Kec. Percut Sei Tuan Kabupaten Deli Serdang sangat antusias, hal ini terlihat dari keaktifan anak-anak dalam bertanya mengenai yang tidak mereka pahami.

b. Pelatihan Penguasaan Kosa Kata

Setelah diberikan sosialisasi awal sebagai pengenalan pengabdian, maka tim pengabdi mengadakan permainan-permainan untuk memperkaya kosa kata anak-anak Padepokan Iqro Desa Kolam Kec. Percut Sei Tuan Kabupaten Deli Serdang yang nantinya akan dituangkan dalam puisi yang mereka tulis.

c. Pembimbingan Menulis Puisi

Setelah mengadakan permainan-permainan, maka selanjutnya anak-anak Padepokan Iqro Desa Kolam Kec. Percut Sei Tuan Kabupaten Deli Serdang dibimbing dalam menulis puisi. Tanya jawab tetap dilakukan sembari anak-anak menuangkan kosa kata yang telah mereka kuasai sebelumnya. Dalam hal ini akan dilakukan penilaian terhadap tulisan yang dihasilkan.

d. Menulis Puisi Secara Mandiri
Setelah tahap pembimbingan sudah dilakukan, anak-anak Padepokan Iqro Desa Kolam Kec. Percut Sei Tuan Kabupaten Deli Serdang menunjukkan masing-masing kemampuannya dalam menulis puisi secara mandiri. Kemudian tulisan yang diperoleh nantinya akan disusun dalam buku ber-ISBN.

\section{B. Pihak yang Terlibat}

Kegiatan pengabdian kepada masyarakat yang dilaksanakan di Padepokan Iqro Desa Kolam Kec. Percut Sei Tuan Kabupaten Deli Serdang ini melibatkan anak-anak Padepokan Iqro Desa Kolam Kec. Percut Sei Tuan Kabupaten Deli Serdang, tim pengabdi, dan mahasiswa Jurusan Bahasa dan Sastra Indonesia.

\section{Peran Peserta}

Peserta berperan aktif dalam mengikuti kegiatan Pengabdian Kepada Masyarakat yang dilaksanakan di Padepokan Iqro Desa Kolam Kec. Percut Sei Tuan Kabupaten Deli Serdang, anak-anak antusias mengikuti kegiatan dari hari pertama sampai kepada hari terakhir, hal ini dapat dilihat dengan keaktifan bertanya para peserta dalam pembinaan kemampuan berliterasi sastra dalam hal ini menulis puisi. Peran Kepala Padepokan Iqro Desa Kolam Kec. Percut Sei Tuan Kabupaten Deli Serdang sangat berkontribusi dalam memotivasi untuk dapat mengikuti selama proses kegiatan berlangsung.

Tabel 1. Peran Peserta dalam Kegiatan

\begin{tabular}{|c|c|c|}
\hline Pertemuan & Tahap yang Dilakukan & Peran Peserta \\
\hline I & $\begin{array}{l}\text { Sosialisasi mengenai konsep dasar literasi } \\
\text { terkhusus konsep dasar puisi. Termasuk di } \\
\text { dalamnya teknik menulis puisi dengan metode } \\
\text { drill (latihan). }\end{array}$ & $\begin{array}{l}\text { Peserta menyimak materi yang } \\
\text { disampaikan tim pengabdi dan tanya } \\
\text { jawab seputar konsep dasar menulis } \\
\text { puisi. }\end{array}$ \\
\hline II & $\begin{array}{l}\text { Pelatihan teknik menulis puisi dengan cara } \\
\text { memperkaya kosa kata anak-anak Padepokan } \\
\text { Iqro Desa Kolam Kec. Percut Sei Tuan } \\
\text { Kabupaten Deli Serdang melalui permainan- } \\
\text { permainan. }\end{array}$ & $\begin{array}{l}\text { Peserta berlatih menulis puisi yang } \\
\text { diawali dengan mengikuti permainan- } \\
\text { permainan yang bertujuan } \\
\text { memperkaya kosa kata. }\end{array}$ \\
\hline III & $\begin{array}{l}\text { Pembimbingan menulis puisi terhadap anak- } \\
\text { anak Padepokan Iqro Desa Kolam Kec. Percut } \\
\text { Sei Tuan Kabupaten Deli Serdang. }\end{array}$ & $\begin{array}{l}\text { Masing-masing peserta diberi } \\
\text { kesempatan untuk menulis puisi } \\
\text { dengan bimbingan pengabdi. }\end{array}$ \\
\hline IV & Praktik menulis puisi secara mandiri. & $\begin{array}{l}\text { Masing-masing peserta menunjukkan } \\
\text { kemampuan menulis puisi yang } \\
\text { dimiliki } \quad \text { setelah dilakukan } \\
\text { pembimbingan menulis puisi. }\end{array}$ \\
\hline
\end{tabular}




\section{Model yang Diterapkan}

Kegiatan pengabdian masyarakat Pembinaan

Desa Kolam Kec. Percut Sei Tuan Kabupaten Deli Kemampuan Berlierasi Sastra di Padepokan Iqro

Serdang dilakukan dengan tahapan sebagai berikut:

Tabel 2. Tahapan Kegiatan Pembinaan

\begin{tabular}{|c|c|c|c|}
\hline No & Tahapan & Kegiatan & Partisipasi Mitra \\
\hline 1 & Persiapan & \begin{tabular}{|ll} 
a. & $\begin{array}{l}\text { Observasi dan wawancara untuk } \\
\text { analisis situasi } \\
\text { mengenai } \\
\text { Pembinaan Kemampuan }\end{array}$ \\
& Berlierasi Sastra di Padepokan \\
& Iqro Desa Kolam Kec. Percut Sei \\
& Tuan Kabupaten Deli Serdang. \\
b. & Membangun komitmen bersama \\
& dengan mitra. \\
c. & Menentukan jadwal kegiatan, dan, \\
d. & Menyediakan segala keperluan \\
& sarana dan prasarana dalam \\
& mendukung terlaksananya \\
& kegiatan pengabdian dengan baik.
\end{tabular} & $\begin{array}{l}\text { Menyiapkan data yang } \\
\text { berhubungan dengan pembinaan } \\
\text { kemampuan berliterasi sastra. }\end{array}$ \\
\hline 2 & Pelaksanaan & $\begin{array}{l}\text { a. Sosialisasi mengenai konsep dasar } \\
\text { literasi terkhusus konsep dasar } \\
\text { puisi. Termasuk di dalamnya } \\
\text { teknik menulis puisi dengan } \\
\text { metode drill (latihan). } \\
\text { b. Pelatihan teknik menulis puisi } \\
\text { dengan cara memperkaya kosa } \\
\text { kata anak-anak Padepokan Iqro } \\
\text { Desa Kolam Kec. Percut Sei Tuan } \\
\text { Kabupaten Deli Serdang melalui } \\
\text { permainan-permainan. } \\
\text { c. Pembimbingan menulis puisi } \\
\text { terhadap anak-anak Padepokan } \\
\text { Iqro Desa Kolam Kec. Percut Sei } \\
\text { Tuan Kabupaten Deli Serdang. } \\
\text { d. Praktik menulis puisi secara } \\
\text { mandiri. }\end{array}$ & $\begin{array}{l}\text { a. Menyediakan tempat pelatihan } \\
\text { selama kegiatan berlangsung } \\
\text { b. Memotivasi peserta agar } \\
\text { antusias mengikuti kegiatan }\end{array}$ \\
\hline 3 & Evaluasi dan Refleksi & $\begin{array}{l}\text { a. Memberikan penilaian terhadap } \\
\text { kemampuan berliterasi sastra } \\
\text { siswa, dalam hal ini menulis } \\
\text { puisi. } \\
\text { b. } \\
\text { Berdasarkan masukan dari tim } \\
\text { pengabdi setelah dilakukan } \\
\text { penilaian dan pembimbingan, } \\
\text { peserta kembali menulis puisi. }\end{array}$ & $\begin{array}{lr}\text { Membantu peserta } & \text { melakukan } \\
\text { perbaikan-perbaikan } & \text { dalam } \\
\text { menulis puisi. } & \end{array}$ \\
\hline 4 & Tindak Lanjut & $\begin{array}{l}\text { Semakin terampilnya peserta dalam } \\
\text { menulis puisi. }\end{array}$ & $\begin{array}{l}\text { Terus berkomitmen } \\
\text { memotivasi dan membimbing } \\
\text { anak-anak Padepokan Iqro Desa } \\
\text { Kolam Kec. Percut Sei Tuan } \\
\text { Kabupaten Deli Serdang dalam } \\
\text { berliterasi sastra. }\end{array}$ \\
\hline
\end{tabular}




\section{KESIMPULAN}

Berdasarkan hasil kegiatan pembinaan kemampuan menulis puisi di Padepokan Iqro Desa Kolam Kecamatan Percut Sei Tuan Kabupaten Deli Serdang yang telah dilaksanakan, maka dapat diambil kesimpulan sebagai berikut:

1. Pada saat tahap sosialisasi dilakukan, anakanak di Padepokan Iqro Desa Kolam mendengarkan mengenai materi yang disampaikan, baik berupa pentingnya literasi sampai dengan teori menulis puisi.

2. Pada saat tahap pembinaan menulis puisi, anak-anak di Padepokan Iqro Desa Kolam fokus dan antusias dalam menulis puisi.

3. Masalah yang timbul dalam kegiatan ini adalah mengetahui unsur-unsur puisi yang akan diproduksi.

4. Rencana dan harapan untuk ke depannya adalah agar program ini dapat mengembangkan minat anak-anak di Padepokan Iqro Desa Kolam dalam berliterasi sastra.

\section{UCAPAN TERIMA KASIH}

Ucapan terima kasih disampaikan kepada Rektor dan Lembaga Penelitian dan Pengabdian Kepada Masyarakat, Universitas Negeri Medan atas dukungan pendanaan melalui program kemitraan masyarakat. Terima kasih juga disampaikan kepada Padepokan Iqro Desa Kolam Kecamatan Percut Sei Tuan Kabupaten Deli Serdang.

\section{DAFTAR PUSTAKA}

Gie, The Liang. 2002. Terampil Mengarang. Yogyakarta: Andi.

Pradopo, Rachmad Djoko. 2005. Beberapa Teori Sastra, Metode Kritik, dan Penerapannya. Yogyakarta: Pustaka Pelajar.

Silaen, Yosefa dan Dian Hasfera. 2018. Membangun Generasi Literat Masyarakat Pesisir Pantai: Gerakan Literasi "Tanah Ombak". Jurnal Perpustakaan, Arsip dan Dokumentasi. Vol. 10, No. 2. https://doi.org/10.15548/shaut.v10

Wurianto, Arif Budi. 2017. Literasi Sastra dalam Masyarakat Belajar (Learning Society). Prosiding SENASBASA. Https: Researchreport.umm.ac.id/ Index.php/SENASBASA.

Zuhairini, dkk. 1983. Metodik Khusus Pendidikan Agama. Suarabaya: Usaha Nasional. 